\title{
Disappointing Indigenous People: Violence and the Refusal of Help
}

\author{
Gillian Cowlishaw
}

Why does she hate me? I didn't even help her.

Aphorism, origin unknown

\begin{abstract}
$R$ ecent revelations about extensive disorder, violence, and misery in Australian Indigenous communities dealt a shocking blow to a nation that deploys, with pride and passion, images of Indigenous people in its self-representations. ${ }^{1}$ The condition of Indigenous people has often been considered a major touchstone of Australia's moral standing in the international arena (e.g., Whitlam 1985: 466). It has been sadly observed that "settler society" consists of immigrant peoples from Europe who tend to cling to the coastal rim and have only a superficial relationship with the vast continent whose heart is inhabited and owned by Indigenous people, with their ancient, spiritual, and nurturant relationship with the land. ${ }^{2}$ This romantic orientation, though only one aspect of public perception, underpins a national goodwill that reached a high point in May 2000 when massive numbers of Australians marched over city bridges in support of "Aboriginal reconciliation" and urged the prime minister to apologize to Abo-
\end{abstract}

1. The capitalized term Indigenous Australians has largely replaced Australian Aborigines because the former includes the racially and culturally distinct Torres Straight Islanders.

2. See Lattas 1997 and Marcus 1997 for anthropological analyses of the deployment of romantic Indigenous imagery in the service of other identities in Australia.

Public Culture 15(1): 103-125

Copyright () 2003 by Duke University Press 
riginal people for the wrongs they had suffered. ${ }^{3}$ Since then a series of revelations about crisis levels of distress - domestic violence, homicides and suicides, drunkenness, child neglect, and sexual abuse-in Aboriginal communities has been widely publicized in the media and in some scholarly works (see Martin 2001; Pearson 2002; Sutton 2001). The widespread public interest in these issues reflects a pervasive and growing disillusionment among those more closely involved with policies of self-determination and the disappointing results of recognizing native title and Indigenous heritage. ${ }^{4}$ Concerned debate now centers on how to rescue Aboriginal communities from violence rather than on how to recognize land rights, heritage, and culture.

I want to examine how we, the concerned citizens of contemporary Australia, are imbued with desire in relation to chronically unequal and needy others, even when they appear to refuse to recognize their need and reject the proffered succor. The unremitting and solicitous national discourse about Aborigines is imbued with urgency and instrumentalism and replete with competing theories of cause and remedy. This discursive field is an unstable mix of the romantic and the statistical, a surface imagery that mirrors the nation's desires and fantasies. The surface does not follow the contours of what lies beneath, that is, the relationship between Indigenous people and the white officials, scribes, and multitude of others they interact with in remote, rural, and urban communities. However, significant connections can be shown between the experience and incidence of Indigenous violence in Australia and the moral universe of redemptive talk, explanation, reproach, and remedy that is a dominant theme in national conversations about Indigenous people. I will explore such connections here, not as cause and effect, but rather as an ongoing living relationship. Because the public realm is a companion of any thinking about Indigenous people in Australia, I will sketch some

3. In Sydney a privately hired plane wrote SORRY repeatedly across the sky as wave upon wave of people poured from buses and trains to walk across the harbor bridge. The numbers exceeded expectations by several thousands; many had to wait hours as more trains and buses were hastily brought into service and the planned two-hour bridge closure was extended until 2 P.M. Perhaps the most powerful contribution to the outpouring of goodwill in the 1990 s was the report on the government's removal of Indigenous children from their families, known as the "stolen generation report" (Wilkie 1997). An annual Sorry Day has now been established.

4. Public debate is famously amnesic, and the nation appears to have forgotten the profound disappointment when it was realized how little land native title applied to and the terrible struggle involved in preserving that little in the first Native Title Act passed by the Labor government in 1993 (see Goot and Rowse 1994). Forgotten also is the anger and disgust experienced by Aboriginal leaders and their supporters when the conservative government in 1996 severely undermined the rights that remained in their "ten point plan" to ensure what they called "security" for landholders. 
major themes of public debate. ${ }^{5}$ My general aim is to identify and unravel some knots that are tying up our thoughts.

I am exploring public opinion and liberal convictions less as problem spaces to be corrected or transcended by intellectual efforts of exposition and explanation than as the cultural realm we inhabit, even though, as an elite minority of academics (with lawyers and others), our work may be dedicated to understanding alterity. Indeed, instead of trying to transform liberal habits and convictions with more sophisticated insights, I want to emphasize the formative power of this cultural realm in the relationship between the nation and Indigenous people. Further, I suggest that some specific forms of what is deemed public disorder among Indigenous people in a rural town can be interpreted as a tangible, radical political analysis and response - a refusal to accept the promises of liberal progress. The nation's myopic concern and limited goodwill can become a burden on Indigenous consciousness.

Much could be said about the form and the shaping of public knowledge, the solicitude and the recent revelations, as well as the disappointment that ameliorative policies appear to have failed. Debates about Indigenous policies and people are often framed by a bogus binary: the rabid Right attacks the left-liberal softies for their misguided ideological commitments, and those known as "progressivists" mount a defensive response, routinely protecting Aborigines from criticism. ${ }^{6}$ A first step in unraveling the knots is to recognize that all the commentators - public and academic, ignorant and well informed, left and right (and within each of these categories, Indigenous spokespersons)_-display a sense of authority and moral duty. There is a common willingness to proclaim knowledge of causes and solutions, but even more pervasive is the display of a sense of virtuous responsibility toward this depressed minority who inhabit what Peggy Brock (1993) and Peter Sutton (2001) have called "outback ghettoes."’ The left/right

5. With many anthropologists engaged in state-sponsored processes of land claims or native title recognition and in government-sponsored research, the discipline is now clearly positioned inside the state and further has become the object of public scrutiny in relation to Indigenous claims to recognition. Bruce Kapferer (2000: 175) has spoken of a "climate of confusion, uncertainty, even vulnerability, in contemporary anthropological circles" because of the loss of its "relatively distinct project" with an epistemology founded on "culture" and "fieldwork."

6. The distinguished Indigenous lawyer and activist Noel Pearson (2000) uses the term progressivist to criticize the liberal leftists with their "human rights agenda" that takes no account of actual conditions. Pearson is breaking down the left/right binary in a number of ways.

7. Sutton uses the term to refer to contemporary Indigenous communities, but Brock was studying the mission regimes of an earlier era, which well may be one site from which current social (dis)order was generated. 
binary provides a sense of discursive danger, with the dominant liberal Left censoring anything that might feed the prejudices of those conservatives and reactionaries who want to deny the value of a distinctive domain of Aboriginality. The simulated contest in which each side exposes the intentions, pretensions, and lies of its opponents conceals the fact that the epistemological and political differences between Left and Right are minor in relation to the gap between these antagonists and the Indigenous people around whom these squabbles are mounted. Further, a distinctive element of national identity is the worry about Aborigines and their injuries, and this worry involves Aborigines as well as the rest of us. These disputes and anxieties ensure that crucial meanings of Australianness and of Aboriginality exist in a fraught and unstable relationship to each other.

Redemptive sentiments toward Indigenous people are played out in a series of conventional antiracist performative or discursive positions characteristic of modern cosmopolitan manners. One such performance consists of being repelled by any repugnance toward otherness. Any expression of distaste for foreign, primitive, or "different" practices is pounced upon and derided as racist; the legitimacy of such distaste, as either experienced or imagined, is vehemently denied. Despite the enthusiasm for diversity, everyday urban lives are distanced from foreign practices, unless they are domesticated in food we ingest, dances we mimic, or the healing techniques we employ. However, mundane conversational forms of approval and disapproval reveal automatic judgments around which everyday identities are constructed. While sophisticated citizens take pride in the appreciation of elements of exotic culture, and deference to difference is automatic among cosmopolitan urbanites, it is always understood that some things are beyond the pale. The conventional admiration of exotic and spiritual Indigenous worlds has been disturbed by recent revelations of Indigenous differences that are labeled unhealthy, chaotic, or cruel.

The public outcry over Aboriginal violence and misery further illustrates the intimate connections between "us" and an imagined "them" who must remain silent and receptive to our ministrations. While the secure ("white") citizens make elaborate welcoming gestures toward those ("black") citizens to whom full citizenship and formal equality were progressively extended in the 1960s (see Beckett 1988; Peterson and Sanders 1998), the latter's radically different aspirations, longings, and lacks can be selectively recognized only for specific, often symbolic, purposes. Gestures such as the Reconciliation Council, Aboriginal units in many professional organizations, and thousands of individuals, expert or not, whose jobs involve liaising between Aboriginal communities and state institutions, are the expression of the nation's goodwill toward Indigenous people, but 
these have not erased older responses of fear, hostility, and mistrust of an irremediable otherness lurking at the margins (e.g., Goldberg 1990; Lane 1998). ${ }^{8}$ These emotions are occasionally visible in slips of the tongue on the public stage, such as a politician's remark about Aborigines' filthy dogs, or when the police are shown on television mocking Aboriginal suicides or caught saying "Boong," a derogatory term for an Indigenous person. ${ }^{9}$ Similarly there is an occasional lapse among Aboriginal leaders, as when the respected Indigenous lawyer Noel Pearson called ministers of the Crown "racist scum." Such public glimpses of a normally suppressed hostility are deemed scandalous, sustaining anxiety about an unresolved problem at the heart of our history that in turn stimulates renewed efforts to normalize the Indigenous domain.

Indigenous individuals who take part in public debate or professional deliberation about their disordered conditions are not themselves the objects of public concern. Or put another way, the denizens of the imagined miserable and violent spaces that the public is now worrying about cannot speak in the same space as we speak our worry. Indigenous people have thus been placed in two mutually exclusive positions: the objects of worry and the consultants to their own problems. Aboriginal leaders are asked to become advisers to the nation, counseling on issues such as the "worrying level of violence in Indigenous communities." This entails their coming inside the nation, speaking within the hegemonic discourse, and giving up disturbing evidence of their otherness, whether exotic or pathetic. That is, Indigeneity must be expressed publicly within a discourse not of Indigenous making. But in local sites, in particular rural and remote communities, an energetic modern Aboriginality is also being constructed under conditions of contestation, misrecognition, and rivalry for moral worth (Cowlishaw 2001b). It is these local manifestations that are being overpowered by the stereotypes of an all-pervasive violence and misery. Violence and misery may be apparent in many communities, but they are only part of a far more complex and interesting story.

8. Originally set up in 1991 as a government-sponsored body dedicated to community education and improved relationships between Indigenous and other Australians, the Council for Aboriginal Reconciliation came into conflict with the reactionary government in power from 1996 and reconstituted itself as an independently funded organization from January 2000 with the original aims of "recognising the gift of one another's presence" and "learn[ing] our shared history" (Grattan 2000: $303-4)$.

9. These cases were publicized on television. A video showing police mocking suicides, shot by police at a "bad taste" party in Bourke, was later stolen in a burglary and subsequently shown on national and international television news broadcasts in early 1992. The commonplace usage of Boong was revealed in Jenny Brockie's documentary on police behavior in the notorious Sydney suburb of Redfern, titled "Cop It Sweet" (Australian Broadcasting Corporation documentary television program, 1993; first broadcast 4 March 1992). 
I am arguing that there exists a widespread narcissistic desire, often muted and pressed into unconsciousness, to improve the Indigenous population. This desire entails solicitous assistance and advice to governments and comprises a substantial bureaucracy, but it is above all preoccupied with fantasies of Indigeneity. The apparent refusal of Indigenous people to be helped, evidenced by their statistically measured marginality, invigorates the desire to understand, intervene, and remedy (Lea 2001). But the lack of success of regenerative policies is also indicative of a cultural alterity that baffles the nation when confronted by it. How can even the most liberal citizens accept the ontological status and reality of the ancestral spirit of Bula, who, if disturbed by a proposed gold mine, would threaten the well-being of the local population (Merlan 1991)? Similarly, protecting Indigenous women's sacred and secret site from development (Bell 1998), outlawing a dam that would interfere with tribal dreaming tracks (Wootten 1994), and recognizing the traditional kinship obligation expressed in a blow to the head (Povinelli 2001) are not propositions easily accepted by the public. In each of these cases there has been a moment of recognition and affirmation by state instrumentalities with the professional help of lawyers and anthropologists, an acceptance of radical alterity for a specific purpose, in a specific context, within a severely circumscribed social reach. This recognition cannot become the basis of mundane, customary negotiation with the nation's other citizens. The recognition of native title-in the widest sense of entitlement to Indigenous cultural practiceis not prefaced merely on rejection of the repugnant and the disturbance of a different deontology (Povinelli 2001) but on its authenticity being tested in the rarefied atmosphere of the courts, among specialist lawyers, anthropologists, and judges who carry a professional and impassioned desire to understand.

With hindsight, it seems obvious that the post-1970s "self-determination" policy was based on ideals that entailed a series of illusions and misconceptions. It was assumed that Aborigines shared the policy vision and that white officials who implemented it were cultureless servants of black aspirations. The funding of autonomous Indigenous organizations was not recognized as itself carrying the weight of colonial history, the civilizing mission, and our intentions and desires for our others. There were no models - what poor and marginal group ever governed itself? To achieve self-determination and gain access to land, Indigenous people faced all kinds of hurdles and complex demands on their subjective orientation and community relations (see Jacobs 1988; Merlan 1995; Povinelli 1998; Rowse 1992; Sanders 1982; Tonkinson and Howard 1990). In particular, the level of interaction between Aborigines and state officials increased exponentially, and, as the difficulties of the new era emerged, even more interaction was required to 

tices became entrenched on the more remote racial frontiers. For example, state

officials acted as ventriloquists, conducting innumerable meetings in partly illiterate communities to procure the communities' required acquiescence for projects that were presented with enthusiasm, though in fact they were often ill conceived and doomed to failure (Cowlishaw 1999). The enthusiasm for selfdetermination blinded its proponents to prevailing economic conditions and to their own cultural baggage. More important for my argument here, proponents gestured eagerly toward cultural difference without grasping the attendant challenges and obligations and without understanding that culture and history are intertwined. The legitimating of cultural difference, especially in the recognition of land claims and native title, was always the target of contempt for those despised as rednecks and populists. Gradually, as the expected benefits were not apparent, as images of black people still sitting in the dust remained on our television screens, and as dispiriting statistics continued to be published, an uneasiness with self-determination and with recognition of Indigenous tradition extended into the most sympathetic and caring segments of the public. The earlier backlash concerned the continued drain on the public purse, which is widely seen to be generous toward Indigenous people. But now there is a perception that the Indigenous social body may be recalcitrant, unable or perhaps unwilling to be helped (Johns 2001), or being offered the wrong kind of help by mistaken politicians or bureaucrats (Folds 2001). In the midst of a generalized goodwill, pity vies with impatience toward those who receive as well as toward those who offer the nation's beneficence.

It may seem perverse to suggest that the national goodwill is itself a source of problems for Aboriginal people. But claims to sympathy and recognition can entail misrecognition and authoritarian solutions. Peter Sutton, a senior anthropologist who has spent many years working on native title claims, epitomizes both the goodwill and, in my view, the misrecognition. ${ }^{10}$ His emotionally charged keynote address to the 2000 annual conference of the Australian Anthropology Society was widely quoted in the press. He asserted that a crisis exists in Indigenous communities: "The contrast between progressivist public rhetoric about empowerment and self-determination on the one hand, and the raw evidence of a disastrous failure in major aspects of Australian Aboriginal affairs policy since the early 1970s,

10. Sutton (2001: 158, n. 3) dismissed in a footnote the community's self-diagnosis that they are not experiencing a health crisis. While not to be taken literally, the community's view provides a challenge to stereotypical public images. See Cowlishaw 2001a for a focused critical response to Sutton. 
is now frightening" (Sutton 2001: 125). He is particularly concerned to make the public aware of the high levels of violence and self-destructiveness that led to the deaths of many of his old friends. It is easy to criticize Sutton's reliance on ahistorical formulations and a crude history/culture binarism, but there is major significance in his explicit affirmation of a national perception that Aboriginal communities are suffering and desperate for help. A number of Aboriginal public figures have also expressed grave concern and demanded government action. In the face of "the statistics of immiserisation" (Havemann 1999: 8), a twenty-year lower life expectancy (Langton 1990), an alcohol epidemic, "welfare poison" (Pearson 2000), and endemic domestic violence and child sexual abuse (Bolger 1991), these Indigenous spokespersons and leaders are calling for a renewal of governments' commitment to improve conditions. ${ }^{11}$ Some of these leaders continue to berate governments for their failures, and others have begun to argue for an end to blame and for a renewal of moral authority at the grassroots level. ${ }^{2}$ Absent from virtually all of these calls for policy change is a commitment to understanding community sentiment and ideas, particularly the manifestations of rage. Apparently anger and violence are such inferior and despicable responses that they cannot be subjected to social analysis.

Another significant aspect of Sutton's essay is that it urged on anthropologists a role they have previously eschewed, that of "Judging Traditions"- the original title of the paper. To anthropology's obligation to experience, understand, illuminate, and depict cultural traditions, Sutton has added the duty to judge them. The published essay was renamed "The Politics of Suffering," a change that may exemplify something that Sutton denounced: the "euphemism, banality and propaganda" (2001: 145) that characterize debates concerning Indigenous matters. Perhaps the change of title indicates that we anthropologists do not allow ourselves to "judge" tradition, just as Sutton is saying that the Australian public, including anthropologists, does not allow itself to name the deplorable conditions

11. A speech made in the Northern Territory Parliament in March 2002 by the relatively new minister on Indigenous affairs, John Ah Kit, himself Aboriginal, also laid out in graphic detail the appalling level of alcoholism, violence, and disorder in Northern Territory communities.

12. The work of Noel Pearson is noteworthy. He is perhaps the most talented, articulate, and sophisticated Indigenous public figure who was closely engaged with the intensely frustrating process of negotiating legislative responses to the High Court Native Title decisions. Pearson abandoned a high-profile career as a barrister or political figure to take up an active role in his community in north Queensland, where his incisive and challenging analysis has identified ideological conditions that operate to retain destructive practices. In particular, he wants it recognized that there is an alcohol epidemic that should be treated in its own right, not as a symptom of historical injury and oppression. However, he has been criticized for exerting his power in undemocratic ways (Satour 2001). 
in Aboriginal communities, especially remote ones. We need, he says, to recognize the contribution made to current ills by specific traditions of violence, of child-rearing, and of kinship ties; Indigenous parents do not teach the discipline necessary for success in modern life, and kinship obligations obstruct adaptation to social conditions that reward individualism. Sutton echoes a widespread conviction that if we were more candid, honest, and intelligent about these matters, the nation's redemptive rationality and undoubted goodwill would kick in to reduce the dire suffering of Indigenous people by transforming their social conditions of existence. Progress, in this view, lies in the exposure of the true conditions to public scrutiny and redress. More intervention, that is, will solve the problems that intervention has caused. 13

The great "we" of the authoritative, well-meaning, and comparatively powerful experts is being urged to find answers to what the same "we" has defined as the problems. But we need to face the possibility that there may not be answers, or not the kind of answers we envisage. It may be that the subjects of our worry reject our concern, our care, and the love we profess. We may be condemned to remain helpless bystanders as people damage themselves and one another. Rejecting our proffered solutions to their problems could be seen as a way in which Indigenous people assert their autonomy from the state's suffocating solicitude.

\section{Repugnant Practices}

The revelation of extensive violence in Aboriginal communities threatens to create a liberal paralysis by appearing to affirm conservatives' assertions that Aboriginal culture is unworthy of recognition. Elizabeth A. Povinelli $(1998,2001)$ has explored the "liberal impasse," that is, the limits of recognition/acceptance of otherness, both in the law - where "repugnant" practices are bracketed off as unrecognizable - and outside it, where the viscerally repugnant may be sought, recognized, and accepted as evidence of the living importance of traditional obligation. In the latter essay Povinelli examines responses to an event at Belyuen that appeared to an experienced native title lawyer as unrestrained "violence" but which she, as anthropologist, could recognize as customary, obligatory punishment. Moreover, the expert anthropologist can identify the act as precisely the type of practice the law of cultural recognition demands as evidence of Aborigi-

13. For this insight I am indebted to Teresa Lea, whose work on bureaucracy has revealed the extent to which this ideological principle underlies the practices of the health bureaucracy. 
nal adherence to customary law - regardless of the practice's actual genealogy. She shows how the court's need to recognize local customary moral obligation resulted in a challenge to its own customary liberal practice of valuing epistemology (rationality) over deontology (moral sensibility). In this case, the local customary obligation was expressed in intensely emotional terms: in the bloody punishment - "bashing" or "killing" in the white and the black vernacular, respectively — of a man for failing in his duty to attend a senior kinsman's funeral. ${ }^{14}$ Thus the customary world of these Belyuen men and the legal world they found themselves within both demanded actions that contravened not only the lawyer's everyday custom but also a fundamental tenet of his profession, that is, the necessity that citizens concede to the state the right to physical retribution. In the eyes of the law this Belyuen man had committed an assault. Whether this physical punishment was or was not traditional in the anthropological sense, the law needed to use it as evidence of the customary obligation it signaled. The court's ability to make such a transformative judgment recognizing the customary obligation in these extraordinary circumstances is also further evidence of the limits of the nation's ability to recognize and legitimate alterity. It is this limit that Povinelli exposes at the heart of the "liberal impasse."

For my purposes, it must be emphasized that the legitimating of "assault" in another jurisdiction is not merely a challenge to the liberal subject's deontology but to the basis of the state's ability to preserve and protect the citizen. That is, outside the specific arena of native title recognition, the liberal subject-lawyer or anthropologist - is likely to value the protection from physical assault as provided by the rule of law, and thus such violence is rarely deemed "cultural." The label cultural attracts an automatic appreciative-often shallow or hypocritical_-performance of recognition, respect, and awe, and to propose this label for what is usually called violence is likely to be met with contemptuous rejection and risks inviting denigration of the very culture under consideration. ${ }^{15}$ The kind

14. I do not have the space to do justice to Povinelli's (2001: 93) incisive argument in which she evokes both the immediate visceral impact and the subsequent struggles to accept the significance of the attack: "The possibility of moral alterity irritated the actual world the lawyer inhabited and the fantasy world he imagined in his legal practice. But it also made his practice serious, weighty indeed, profound." The lawyer's sense of special status was boosted by a precious sense of being privy to a world where value was conferred on what was negatively valued in his own domain.

15. This is evident in relation to public discussion about the practices of Afghani asylum seekers who have landed in Australia. If their behavior appears repugnant, defending it as "cultural" would exacerbate the widespread hostility to their being treated more humanely. Likewise, anthropologists prefer to remain silent about elements of Aboriginal tradition, such as the customary marriage age of girls in Arnhem land. Cornelius Castoriadis (1992) evoked the sophisticated cosmopolitan's experi- 
of culture that receives automatic respect is old culture, culture without history. The ability of the law to recognize a violent act as cultural may depend not only on it being authenticated as a stable tradition, part of an older social formation, but also on it being located in a remote place, in a marginalized community, and not likely to invade urban spaces as legitimated practice. But I want to take Povinelli's argument further by asking: What if the status of the blow were more obscure and ambiguous, not identifiable as an expression of customary obligation? Can we, as anthropologists, transpose this recognition of "repugnant" elements of culture to the realm of social disorder that is said to be characteristic of remote and urban Aboriginal communities? That is, is there some "still resistive system in the scene" (Povinelli 2001: 93) in communities allegedly riven by violence and alcohol abuse, or has disorder replaced any system or culture?

To clarify my approach to questions of violence and ethnography I want to consider Ted Swedenburg's comments on the work of Jean Genet. After describing the "idiotic delight" experienced by Genet when he was with the Palestinians under fire (described in Genet's Prisoner of Love [1989]), Swedenburg comments ironically: "Strange motivations. What could they have to do with ethnography? Is doing ethnography in a hazardous field really supposed to be a question of fun, or love? Aren't we supposed to be attracted to intriguing intellectual problems? Isn't it magnanimity that compels us to live with the wretched of the earth?" (Swedenburg 1995: 30). It seems to me that if we lose sight of "question[s] of fun, or love," we are lost in a world where life_-including the life of the ethnographer - is merely endured. We are then led by the nose to governmental questions about how we can fix what they suffer and to superimposing our common sense that "violence and its consequences are automatically associated with aberrant cultural difference" (Feldman 1994: 405) before the work of ethnography has even begun. It is moments of idiotic delight, as well as a recognition of elements of myself in some wild, raging moments with Murri (local Aboriginal) friends and in the feelings of exasperated citizens whose lives are disrupted, that have led me to this kind of analysis.

In the ethnographic illustration that follows, attention is limited to public expression of the kind of violence that attracts disapproval and legal sanction, that is, physical violence - typically blows to the body enacted in public — and

ence of these limits in a scene where an employee or respected friend is preparing for the ceremony of his daughter's infibulation. Dealing analytically with domains usually deemed disordered or repugnant can attract the accusation of legitimating what we should be condemning as regressive (Pettman 1991; Rowse 1990). 
the destruction of property. Related forms of violence such as the verbal violence of derogation that can be manifested as a blow to the psyche, causing painful visceral reactions, are not dealt with here, and the domestic violence that attracts frequent police attention in rural Aboriginal communities is only mentioned in passing. But the acts I describe are grounded in substantive webs of social and historical forms of connectedness and thus illustrate crucial characteristics of social relations in this cultural arena.

\section{The Genealogy of the Broken Windows}

My fieldwork diary of 15 March 1998 reads: "The main street of Bourke is fully boarded up after $5.30 \mathrm{pm}$. Sheets of metal or board over nearly all the windows of shops etc. It looks blank, bleak, worse than when I was here in the 1980s." The shop windows are protected for good reason - the practice of breaking them is well entrenched and familiar, and no one now denies that young Aborigines are responsible. A few months previously, on a hot December night, a series of events occurred that were reported in the metropolitan press under the headline, "Rioters Tear up Bourke":

The far north-west town of Bourke was counting the cost yesterday after more than 150 drinkers rioted overnight, attacking police with rocks and bottles and vandalised shops and offices. Nine police were injured in the melee and thousands of dollars worth of damage was done to premises when drinkers fighting among themselves turned on police — and the town. Shopkeepers described the riot as one of the worst acts of mass vandalism in Bourke's history. Police said yesterday the drama began shortly after 10 pm on Friday when Aborigines mingled outside the Post Office Hotel in Oxley Street after a night of drinking and karaoke singing. Fights broke out in the crowd and about 10 police officers - almost Bourke's total police strength — rushed to the hotel. 16 "But the crowd became hostile and turned on police," a police spokesman told the Sun-Herald. The officers retreated to the police station, regrouped and went back onto the streets. But the crowd began throwing rocks and bottles at them, their vehicles and the police station. (Warnock and Bye 1997b)

16. In fact thirty police were stationed in Bourke, a town of under 3,000 people. Some were no doubt on leave or out of town, but this hugely inflated police establishment is testament to previous moral panic and lobbying of the shopkeepers and other residents against a perceived threat to livelihood and propriety (Cunneen and Robb 1987). 
The report included the comment of a shop owner: "Everyone here are just hard-working small-business operators - they're not racists," and concluded, "Last night police were searching for several of the rioters." Another item in the same paper reported that ten suspects were arrested on thirty-six charges, "including affray, assaulting a police officer, use of a weapon with intent and violent disorder" (Warnock and Bye 1997a).

There is a body of thought, articulated by left-liberal academics and lawyers from Aboriginal legal aid services, that is quick to explain this kind of social disorder as a symptom of historical injury stemming from colonial dispossession. In this view, Aborigines are bored and depressed, police target them unfairly, and whites who own the shops are rednecks anyway. While destructive actions are not excused, the rioters are pitied for being without work and without culture, bored and aimless. The legal aid lawyers and some magistrates recognize that they are dealing with social problems of the powerless and marginalized. A few academic analyses have concentrated on the oppressive conditions Aborigines experience. Chris Cunneen (1990, 2001) and Cunneen and Tom Robb (1987) have shown how violence toward Aborigines is common, and Esther Alvares (1998) has documented the bizarre parade of Aborigines before the Bourke court, many charged with minor public order offenses and receiving increasingly long sentences. Barry Morris (2001) has convincingly demonstrated the significance of police paranoia and fantasy concerning the sinister power and cunning of the Aboriginal population. I do not dispute the significance of these findings, but they do not challenge the image of depressed and unthinking perpetrators, and such images do not accord with my experience in Bourke. Besides social distress among Murris, there are also passion and intent, satire and humor, and there are organic intellectuals whose understanding of the social world they inhabit is more sophisticated than that of many urban commentators.

The kind of reasoning that appears to exonerate the perpetrators of the Bourke riot seems a weak and unsatisfactory way to address what are frequent, passionate, and indeed sometimes bloody conflicts, engaging the attention of many people and many resources over considerable periods of time and sometimes involving long prison sentences. A series of similar disturbances here and in other towns constitutes the climacteric moments of an entrenched struggle, more often seen in particular conflicts between a segment of the Murri population and the police. Unlike populist and punitive responses, liberal thinkers do not attribute agency or serious purpose to the perpetrators of these acts. I contend that these people are responsible for actions that deliberately challenge the hegemony, not only of police but also of the town's establishment, as well as of 
Aboriginal legal aid lawyers and liberal academics. That is, these "rioters" are not merely responding destructively and self-destructively to conditions not of their own making; they are also, among other things, creating the political (Feldman 1997) and at the same time experiencing the elation of a highly charged expressive moment. One specific intention of those rioters who frequent the pub is to redress the humiliation they have often experienced in their interaction with police. However, intentionality by no means exhausts the meaning of these actions. I suggest that riotous fury is the public edge of a deeply felt sense of ongoing injustice that is built into Aborigines' customary understanding of the social world. These sentiments have been nurtured and replenished, not only by experiences of secretly or openly hostile local residents but by the national attention and misrecognition where the Indigenous population is construed as an ever present national problem.

But how do sympathetic and conciliatory explanations for their actions accord with the understanding of local Aboriginal people? What do they say about these incidents? It is a minority of those who call themselves blackfellas or Murris who take part in the so-called riots. Among those not personally involved, some are as angry as the shopkeepers - fed up, they say, with having to wear the reputation of a destructive community. Many others display a degree of fellow feeling with the "rioters." For instance Bill, who is neither a drinker nor a fighter, told me, "If they'd been one block down they would never have been seen. I don't think the police would've even got involved in the fight. It started too close to the police station." ${ }^{17} \mathrm{He}$ explained that there was a long-standing tradition of informally organized fights within the community (see also Langton 1988; McDonald 1988).

On a Friday or Saturday night a few years ago, "You could dance "til about three and watch the fights "til about five.... People were fighting with their fists. It was just like going into one of those Michael Tyson boxing rings." This description of a community of people enjoying a stoush, or brawl, among family and friends as they have always done on the weekends and defending themselves against intrusive police, contrasts remarkably with the media description of a menacing crowd of "rioters" who "tore up Bourke." Such transformations of people and events are one aspect of an entrenched struggle concerning identity, control of space, and the legitimacy of citizenship that pervades the social life of Bourke.

Alex, an Aboriginal man who faced serious charges as a result of the so-called riot and who has a long history of conflict with police, explained:

17. All names have been changed. 
There was just a blue in the main street, and it happened to be my nephew that was in the blue... these two blokes was wanting to have a go at him. ${ }^{18}$ So I went over and I intervened, and a couple of hits were thrown. Then next minute this policeman came out of nowhere, and I said to him, "Why didn't you stop it when it started down the street down here? Yous all scared or what? What are you doing in uniform? Gutless bastard." . . And something I said there, well, he said to me, "Go on hit me big man, hit me," like that. I couldn't pass up a chance like that. I went whack and I hit him once under the chin and knocked him out. And I'm supposed to have started the riot! I can't see how I started the riot.

Two cops come at me and one hit me with a baton. I was on the ground then.

In the melee he managed to crawl away and "Me and [my nephew] just sat in the gutter talking. I said 'Don't worry about it, bugger it' and I walked home." The picture Alex evokes is of someone at home in this social environment, defending his nephew and his honor in response to the policeman's provocative invitation. These familiar satisfactions were disturbed when, instead of being able to plead guilty to hitting a policeman, he "ended up with all these charges, nine charges," which were not finally resolved for another three years.

A further examination of the riot narrative will allow us to retrieve additional meanings, which are usually concealed beneath the orthodox outraged or concerned responses. If the police enthusiasm to quell the "riot" was intended to protect the property of those who have lobbied so hard for more stringent and punitive policing (Cunneen 1989), then the attempt failed miserably. The police soon became the object of attack and retreated to the police station to don riot gear. They then drove three police vehicles out of the yard and parked them facing along the main street with their lights on full, thus confronting the boisterous, inebriated crowd with the glare and menace of police power. This is when shop windows were broken and looting began. Thus it seems that the perception that the noisy, fighting crowd of Aborigines represented a serious threat to law and order was what actually evoked the anger and destructiveness. The harmony between shopkeepers' convictions and police paranoia concerning Aborigines' power and cunning (Morris 2001) opened a space for the performance of rage. The violence is an answering back that says, in effect, "You treat us as a threat? Well yes, we are!" It is as if the police action gave permission for the crowd to fulfil the awful fantasies of disorder and mayhem that hover on the edge of white

18. A blue is a common Australian vernacular term for a fight. 
consciousness. Having been summonsed into being as an ugly menace, the crowd was empowered to act accordingly.

I am suggesting, moreover, that these acts of rage force political matters into view. A politicized narrative is produced that inverts the moral hierarchy of white virtue and black sin. For a moment the police are made the aggressors, threatening irrational force in a homely, domestic space. Stones are thrown at shop windows with an "ideological rationality" that "create[s] the political" (Feldman 1997: 37) by mounting a symbolic challenge to the ownership and propriety that police powers support. Black violence is deployed to create a productive space where racialized bodies carry powerful messages. Because the poetics of black community life remain subject to what Allen Feldman (1997: 43) calls a "realist scopic regime" with its insistence on homogeneity, violent actions are needed to shatter the complacency and moral superiority that accompanies and naturalizes state power. Breaking windows restores the honor that is lost when police enter the domestic sphere or interrupt sociality in the pubs. Violent destruction is also a counter to expected deference and a response to fear and hatred, as well as a justification of it. These meanings have been built, in part, on an understanding of the fear and censure of violence in the white world.

This is not an argument about the consequences or function of rioting in the streets of country towns but for recognizing that events that are routinely rendered as pointless and destructive mayhem are also part of an ongoing "conversation" between Aborigines and the police who represent the state and the nation. The one report of the riot in the metropolitan tabloid functioned to affirm the violence that, as Feldman (1994: 404) says, defines the other, the outsider, confirming "the exceptionalism of the historical and geographical periphery." Violence, whether used against Aborigines or by them, is an abnormality and an embarrassment in egalitarian Australia. ${ }^{19}$ When police threaten social honor (through their violence, their contempt, and their perceived invulnerability, as well as through reliance on them to quell domestic disputes and stop Murris hurting one another) extreme measures are taken in response: broken windows and spectacularly damaged houses become the public symbol of racial power, defying both police and the alien white citizens who control the town. The visual testament to this power remains in the spectacle of the boards and metal shutters that hide the repeatedly and publicly smashed windows of the shops in the main

19. Journalists play on the seductive power and visceral excitement in the fulsome expression of destructive rage in public. Readers are invited to enjoy the violence vicariously and secretly, while simultaneously affirming a proper moral outrage. 
street. ${ }^{20}$ But while violence may "create the political," its effects cannot be contained within this inchoate intention to draw attention to the realities of state power and social injustice. Police are privy to demeaning domestic conditions when they are called to settle drunken disputes. As one Murri man said: "Fighting between ourselves causes a lot of family problems. But you get the police involved in it, and on top of having a fight with your best mate, then you got ten charges for what the cops picked you up for when they tried to stop it." Aborigines, both inadvertently and intentionally, evoke and also play on police anxiety and paranoia. The racist images that are sometimes glimpsed in public discourse can be enacted and exaggerated in rowdy street performances that shock and challenge white fears. A bitter, black satirical humor about race relations is also part of Murri discourse (Cowlishaw 2001b). Just as Alex and other Murris imagine police denigrating and laughing at them, so police imagine themselves being mocked and undermined by the Aborigines they try to control.

This riot defies the good liberal citizen's internalization of the legal notion that violent settlement of disputes is wrong because it breaches the principles of rationality and purpose. Physical punishment is acceptable for children and convicts, but it should be enacted without affect. The cool, cruel violence of correction, containment, or punishment is deemed rational, while violent actions performed in rage are deemed irrational, uncontrolled, and frightening. ${ }^{21}$ The former is characterized by intentionality to affect another person; the latter may cause hurt, but it is defined by its expressive nature. This contrast emerges in social conditions where a subordinated segment of the population is the object of systematic benign or derogatory inferiorization. The subordinates' vehemence can be expressive, fearful, and shameless and is directed toward those whose control depends on a violence that is usually hidden and denied or deemed necessary and legitimate. The structure of the racialized relationship between whitefellas and blackfellas in rural Australia is of this kind. The white parental fantasy of anxiety and control, usually enacted with cool conviction and unawareness, evokes violent responses. This violence is thus part of an interchange where one speaks with authority, drowning out the other's shouts of frustration at being unheard. As the

20. The solution has been found in the installation of metal roller blinds that the council subsidizes with assistance from the state government using a fund made up of monies confiscated from urban criminals.

21. Friedrich Nietzsche (1994: 59) observed that "the mere sight of judicial procedures prevents the criminal from feeling bad about his act because he sees the same kind of action practiced in the service of justice and given approval, practiced with good conscience . . . carried out without even having emotion as an excuse" (emphasis added). 
subordinate's passionate crimes against injustice are committed, the superordinate's cool reason becomes more anxious and punitive, compounding the felt injustice. Like the abject patient in a hospital gown who is assessed by welldressed competent adults, there is a sense of being prejudged as incompetent. Any protest can only confirm the judgment, which is perceived in helpless rage.

\section{Finale}

The blows exchanged when a street fight among Aboriginal people in Bourke is interrupted by police are never labeled cultural, despite their being part of a wellrecognized traditional exchange. They also come to the attention of a court, but in these magistrates' or district courts there is no space to recognize otherness as culture or history but only as pitiable and reprehensible evidence of marginality. In the public arena, and in academic analysis (Bolger 1991; Sutton 2001; Tatz 2001) with few exceptions (Robinson 1995; Cowlishaw 1988), Indigenous violence can be examined only as a pathology, a symptom of colonial injury. If one does not join the universal opprobrium, the hounds of moral policing start to bay. Such moral hegemony obstructs the exploration both of local meanings attached to particular violent events and of the historical dimension of such cultural expression. So, while violence is always cultural in the sense that it exists within social relations, accrues local meanings, and exhibits norms and transgressions, it is not open to me to publicly endorse it as cultural. It will never have a part in affirming native title or be cited as an element of heritage. It cannot attract the kind of respect accorded to alterity. My aim has thus been more modest: to show the sense violence makes in reproducing a cultural domain wherein the relationship between white and black citizens gets played out as a realm of tension and conflict and as a source of racial identities.

The orthodox objection to violence in social relations reflects a culturally cultivated revulsion toward the kind of power wielded through the threat and practice of brutality and physical pain. This objection has prevented the analysis of the entrenched, normalized place of violence in modern society, which in turn perpetuates confusion between, for instance, violence as evidence of moral strength and of moral weakness. Denying the normalcy of violence removes crucial forms of sociality and of governance from scrutiny, such as the duplicity, hypocrisy, and secrecy that surround the legal and illegal use of violence by police. I have argued that among Indigenous peoples, there is a social disposition 
toward wrath generated by historical and current circumstances. The breaking of shop windows also engages the logic of terrorism — as an expression of rage and frustration that systematic injustice and derogation are refused recognition. Further, as I have shown elsewhere (Cowlishaw 2001b: 160), the assertion of egalitarian nondiscriminatory practice can contribute to the consuming rage manifested on the main street of Bourke that December night.

Why, in the face of the goodwill that marked the moral ascendancy of selfdetermination and land rights in the last thirty years, have Aboriginal people not snuggled comfortably into the warm and welcoming embrace of the nation? This kind of question is implied in much public discourse and reminds us that we cannot dismiss the recognition of culture and heritage as merely a shallow cloaking of a deeper rejection of alterity. The impulses and sentiments that support recognition constitute a real condition of existence for Indigenous people, but they can be a stifling fog, concealing painful experiences of interracial interaction and drowning emotional impulses in conventional sympathy. It is useful, I suggest, to imagine public violence as a way of breaking through the suffocating, complacent facade of national solicitude. Rioting can be seen as expressing rage consequent on the recognition that true recognition never occurs.

Gillian Cowlishaw is a senior research fellow at the University of Technology, Sydney, Australia. Her most recent book is Rednecks, Eggheads, and Blackfellas: A Study of Racial Power and Intimacy in Australia (1999).

\section{References}

Alvares, Esther M. 1998. Police charging in Bourke 1980-1992. Master of laws thesis, University of Sydney.

Bauman, Toni. 2001. Shifting sands: Towards an anthropological praxis. Oceania 71: 202-25.

Beckett, Jeremy. 1988. Aboriginality, citizenship and the nation state. In Aborigines and the state in Australia, edited by Jeremy Beckett. Adelaide, Australia: Social Analysis.

Bell, Diane. 1998. Ngarrindjeri Wurruwarrin: A world that is, was, and will be. North Melbourne: Spinifex.

Bolger, Audrey. 1991. Aboriginal women and violence: A report for the Criminology Research Council and the Northern Territory Commissioner of Police. Darwin: Australian National University, North Australian Research Unit. 
Brock, Peggy. 1993. Outback ghettos: Aborigines, institutionalisation, and survival. Cambridge: Cambridge University Press.

Castoriadis, Cornelius. 1992. Reflections on racism. Thesis Eleven 32: 1-22.

Cowlishaw, Gillian. 1988. Black, white or brindle: Race in rural Australia. Melbourne: Cambridge University Press. 1999. Rednecks, eggheads, and blackfellas: A study of racial power and intimacy in Australia. Ann Arbor: University of Michigan Press.

—. 2001a. Euphemism, banality, propaganda: Anthropology, public debate and Indigenous communities. Paper presented at the Double Edged Conference, Newcastle University, 30 November.

- 2001b. Performing Aboriginality: The politics and poetics of citizenship in everyday life. UTS Review 7: 153-69.

Cunneen, Chris. 1989. Constructing a law and order agenda. Aboriginal Law Bulletin 2: 6-9.

-1990. Aborigines and law and order regimes. In Contemporary race relations in Australia, edited by Barry Morris and Gillian Cowlishaw. Bathurst, New South Wales: Centre for Social Justice Studies.

- 2001. Conflict, politics and crime: Aboriginal communities and the police. Crows Nest, New South Wales: Allen and Unwin.

Cunneen, Chris, and Tom Robb. 1987. Criminal justice in north-west New South Wales. Sydney: N.S.W. Bureau of Crime Statistics and Research.

Feldman, Allen. 1994. On cultural anesthesia: From Desert Storm to Rodney King. American Ethnologist 21: 404-18.

- 1997. Violence and vision: The prosthetics and aesthetics of violence. Public Culture 10: 24-60.

Folds, Ralph. 2001. Crossed purposes: The Pintupi and Australia's Indigenous policy. Sydney: University of New South Wales Press.

Genet, Jean. 1989. Prisoner of love, translated by Barbara Bray. London: Pan.

Goldberg, David T. 1990. Anatomy of racism. Minneapolis: University of Minnesota Press.

Goot, Murray, and Tim Rowse. 1994. Make a better offer: The politics of Mabo. Leichhardt, New South Wales: Pluto.

Grattan, Michelle. 2000. Reconciliation: Essays on Australian reconciliation. Melbourne: Bookman.

Havemann, Paul. 1999. Indigenous peoples' rights in Australia, Canada and New Zealand. Auckland: Oxford University Press.

Jacobs, Jane M. 1988. The construction of identity. In Past and present: The con- 
struction of aboriginality, edited by Jeremy Beckett. Canberra: Aboriginal Studies Press.

Johns, Gary, ed. 2001. Waking up to dreamtime: The illusion of aboriginal selfdetermination. Singapore: Media Masters.

Kapferer, Bruce. 2000. Star wars: About anthropology, culture and globalisation. Australian Journal of Anthropology 11: 174-98.

Lane, Christopher. 1998. The psychoanalysis of race. New York: Columbia University Press.

Langton, Marcia. 1988. Medicine square. In Being black: Aboriginal cultures in "settled" Australia, edited by Ian Keen. Canberra: Aboriginal Studies Press.

- 1990. Too much sorry business. Report for the Royal Commission into Aboriginal Deaths in Custody, Canberra, Australia.

Lattas, Andrew. 1997. Aborigines and contemporary Australian nationalism. In Race matters: Indigenous Australians and "our" society, edited by Gillian Cowlishaw and Barry Morris. Canberra: Aboriginal Studies Press.

Lea, Teresa. 2001. A benign arithmetic: Taking up facts about Indigenous health. UTS Review 7: 59-73.

Marcus, Julie. 1997. Journey out to the centre. In Race matters: Indigenous Australians and "our" society, edited by Gillian Cowlishaw and Barry Morris. Canberra: Aboriginal Studies Press.

Martin, David. 2001. Is welfare dependency “welfare poison"? An assessment of Noel Pearson's proposals for Aboriginal welfare reform. CAEPR discussion paper 213/2001. Canberra: Centre for Aboriginal Economic Policy Research (CAEPR), Australian National University.

McDonald, Gaynor. 1988. A Wiradjuri fight story. In Being black: Aboriginal cultures in "settled" Australia, edited by Ian Keen. Canberra: Aboriginal Studies Press.

Merlan, Francesca. 1991. The limits of cultural constructionism: The case of Coronation Hill. Oceania 61: 341-52.

- 1995. The regimentation of customary practice: From Northern Territory land claims to Mabo. Australian Journal of Anthropology 6: 64-82.

Morris, Barry. 2001. Policing racial fantasy in the far west of New South Wales. Oceania 71: 242-62.

Nietzsche, Friedrich. 1994. On the genealogy of morality, translated by Carol Diethe. New York: Cambridge University Press.

Pearson, Noel. 2000. Our right to take responsibility. Cairns, Queensland: Noel Pearson and Associates. 
. 2002. Outline of a grog and drugs (and therefore violence) strategy. Manuscript.

Peterson, Nicolas, and Will Sanders, eds. 1998. Citizenship and Indigenous Australians: Changing conceptions and possibilities. Cambridge: Cambridge University Press.

Pettman, Jan. 1991. Racism, sexism and sociology. In Intersexions: Gender, class, culture, ethnicity, edited by Gillian Bottomley, Marie M. de Lepervanche, and Jeannie Martin. St. Leonards, New South Wales: Allen and Unwin.

Povinelli, Elizabeth A. 1998. The state of shame: Australian multiculturalism and the crisis of Indigenous citizenship. Critical Inquiry 24: 575-610.

- 2001. Bound and gagged: The state of morality in the politics of recognition. UTS Review 7: 74-95.

Robinson, Gary. 1995. Violence, social differentiation and the self. Oceania 65: $323-46$.

Rowse, Tim. 1990. Are we all blow-ins? Oceania 61: 18-91.

1992. Remote possibilities: The Aboriginal domain and the administrative imagination. Darwin: North Australian Research Unit, Australian National University.

Sanders, Will. 1982. From self-determination to self-management. In Service delivery to remote communities, edited by Peter Loveday. Darwin: North Australian Research Unit, Australian National University.

Satour, Trevor. 2001. The new authoritarian separatism. In Waking up to dreamtime: The illusion of aboriginal self-determination, edited by Gary Johns. Singapore: Media Masters.

Sutton, Peter. 2001. The politics of suffering: Indigenous policy in Australia since the 1970s. Anthropological Forum 11: 125-73.

Swedenburg, Ted. 1995. With Genet in the Palestinian field. In Fieldwork under fire: Contemporary studies of violence and survival, edited by Carolyn Nordstrom and Antonius C. G. M. Robben. Berkeley: University of California Press.

Tatz, Colin. 2001. Aboriginal suicide is different: A portrait of life and selfdestruction. Canberra: Aboriginal Studies Press.

Tonkinson, Robert, and Michael Howard, eds. 1990. Going it alone? Prospects for Aboriginal autonomy: Essays in honour of Ronald and Catherine Berndt. Canberra: Aboriginal Studies Press.

Warnock, Steve, and Clarissa Bye. 1997a. Bourke riots: 10 charged. Sun-Herald, 7 December, 6.

. 1997b. Rioters tear up Bourke. Sun-Herald, 7 December, 11. 
Whitlam, Edward Gough. 1985. The Whitlam government, 1972-1975. Ringwood, Victoria: Penguin.

Wilkie, Meredith. 1997. Bringing them home: Report of the national inquiry into the separation of Aboriginal and Torres Strait Islander children from their families. Sydney: Human Rights and Equal Opportunity Commission.

Wootten, Hal. 1994. The Alice Springs dam and sacred sites. In Make a better offer: The politics of Mabo, edited by Murray Goot and Tim Rowse. Sydney: Pluto. 


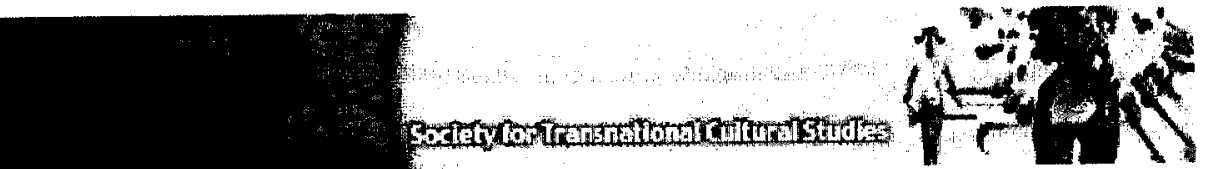

\section{Guidelines for Contributors}

\section{Essays:}

1. Style

Authors may refer to the guidelines of The Chicago Manual of Style, though both British and American spellings, and combinations of the two, will be respected. Spellings should, however, be consistent within an article. Authors are requested to conform to Public Culture's style guide, especially in regard to citation style. The Public Culture style guide is available at www.uchicago.edu/research/jnl-pub-cult.

\section{Format}

Manuscripts should be submitted in triplicate, double-spaced throughout, including notes. A double-spaced list of "Literature

ited" should be attached, as well as double-spaced endnotes. The tont for all text should be Times Roman 12-point. A short biographical note should be included on a separate sheet, stating the author's institutional affiliation, relevant recent publications, and current research. Please do not use running heads.

\section{Length}

The entire manuscript-text, quotations, references, endnotes-should be double-spaced and should be no longer than thirty-five pages (approximately 9,000 words). Please use endnotes rather than footnotes. In some cases authors may be requested to shorten essays.

4. Camera-ready copy

Any photographs or illustrations must be of good quality.

Photocopies of photographs are usually not acceptable. Please provide, on a separate page, a caption for each illustration. All photographs will be retumed to authors after review or publication.

zctronic images may also be submitted.

\section{Permissions}

The author is responsible for obtaining written permission to reprint any illustrations. Please consult the editorial staff with any questions.

\section{Diskettes}

Authors of manuscripts accepted for publication will be asked to submit final versions by e-mail attachment or on a 3.5-inch Macintosh formatted diskette, preferably in Microsoft Word.

\section{Groups of essays:}

Groups of essays on a single topic or theme may be considered for publication in a special issue or special feature of Public Culture. Please submit all papers together, following the guidelines above, plus:

${ }^{\star} A$ short (one-page) description of the common 
intellectual project of the group of papers.

*A list of the titles of the papers, their authors, and the authors' names and addresses.

${ }^{\star} A$ very short (250-word) abstract of each paper.

\section{Visual essays:}

Public Culture welcomes submissions of original photoessays or other visual essays, with or without an accompanying text.

\section{Camera-ready copy:}

Please submit camera-ready copy, preferably in black-and-white. For photographs, $8 \times 10$ inch black-and-white glossy prints are strongly preferred.

"Layout: Artists submitting visual essays should bear in mind that all essays will begin on a recto (right-hand) page. Final decisions regarding layout will rest with the Editor.

*The journal's specs: A page of Public Culture measures $7 \times 8-1 / 2$ inches. Typefaces used in the production of the journal include: China Smallcaps, Gill Sans Bold Condensed, and Times Roman.

If more information is needed, please consult the editorial office. If you wish us to return your images, please send a self-addressed, stamped envelope.

The author is responsible for obtaining written permission to reprint any illustrations. Please consult the editorial staff with any questions.

Where to send your submissions:

The Editor

Public Culture

University of Chicago

1010 East 59th Street

Chicago, IL 60637

Phone: 773-702-0814

fax: 773-702-9861

e-mail: public-culture-journal@uchicago.edu

Approximate schedule: Essays accepted for publication will generally be published within nine to twelve months of receipt. This schedule is somewhat flexible, however, and subject to various contingencies. If you have a particular concern about timing, please consult the editorial office.

\section{Muse Search Journals This Journal Top}

http://muse.jhu.edu/journals/public_culture/information/guidelines.html. 


\section{Public Culture}

Volume 15, Number 1, Winter 2003

Special Issue: Violence \& Redemption Guest Editor: Late Liberalism Collective
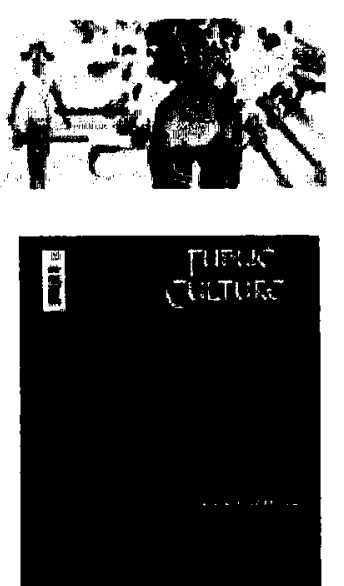

\section{Contents}

- Editor's Note

- from the field

\section{Violence and Redemption}

Vogler, Candace A.

Markell, Patchen, 1969-

- Introduction: Violence, Redemption, and the Liberal Imagination

[Access article in HTML] [Access article in PDF]

Mbembé, J.-A., 1957-

Meintjes, Libby, tr.

- Necropolitics

[Access article in HTML] [Access article in PDF]

Subjects:

- Sovereignty.

- Life and death, Power over.

Warner, Michael, 1958-

- What Like a Bullet Can Undeceive?

[Access article in HTML] [Access article in PDF]

Subjects:

- Melville, Herman, 1819-1891. Shiloh.

- United States -- History -- Civil War, 1861-1865 -Literature and the war.

Graves, Ken, 1942-

Lipman, Eva, 1946-

Werry, Margaret.

- Man: An American Assay

[Access article in HTML] [Access article in PDF]

Subjects:

- Men -- United States -- Portraits. 
Hage, Ghassan.

- "Comes a Time We Are All Enthusiasm": Understanding

Palestinian Suicide Bombers in Times of Exighophobia

[Access article in HTML] [Access article in PDF]

Subjects:

- Suicide bombers - Middle East -- Psychology.

- Suicide bombings -- Middle East.

- Palestinian Arabs -- Psychology.

Blackmore, Tim.

- Rotor Hearts: The Helicopter as Postmodern War's

Pacemaker

[Access article in HTML] [Access article in PDF]

Subjects:

- Military helicopters.

- War.

Cowlishaw, Gillian.

- Disappointing Indigenous People: Violence and the Refusal

of Help

[Access article in HTML] [Access article in PDF]

Subjects:

- Australian aborigines -- Government relations.

- Australian aborigines - Social conditions.

- Australia -- Politics and government -- 1945-

Lomnitz-Adler, Claudio.

- Times of Crisis: Historicity, Sacrifice, and the Spectacle of

Debacle in Mexico City

[Access article in HTML] [Access article in PDF]

Subjects:

- Mexico -- Economic conditions - 1982-1994.

- Mexico - Politics and government --20th century.

- Mexico - Social conditions - 1970-

Kusno, Abidin, 1966-

- Remembering/Forgetting the May Riots: Architecture,

Violence, and the Making of "Chinese Cultures" in Post1998 Jakarta

[Access article in HTML] [Access article in PDF]

Subjects:

- Riots - Indonesia - Jakarta.

- Chinese - Violence against - Indonesia - Jakarta.

- Architecture -- Indonesia -- Jakarta.

\section{Reconciliation and Response}

Sampson, Steven L.

- From Reconciliation to Coexistence

[Access article in HTML] [Access article in PDF]

Subjects:

- Borneman, John, 1952- Reconciliation after ethnic cleansing: listening, retribution, affiliation. 
- Reconciliation.

- Ethnic relations.

Wilson, Richard, 1964-

- Justice and Retribution in Postconflict Settings

[Access article in HTML] [Access article in PDF]

Subjects:

- Borneman, John, 1952- Reconciliation after ethnic cleansing: listening, retribution, affiliation.

- Reconciliation.

- Human rights.

Falk, Richard A.

- Doubting the Unconditional Need for Retribution [Access article in HTML] [Access article in PDF]

Subjects:

- Borneman, John, 1952- Reconciliation after ethnic cleansing: listening, retribution, affiliation.

- Reconciliation.

- Retribution.

Nader, Laura.

- Departures from Violence: Love Is Not Enough [Access article in HTML] [Access article in PDF] Subjects:

- Borneman, John, 1952- Reconciliation after ethnic cleansing: listening, retribution, affiliation.

- Reconciliation.

- Ethnic relations.

Borneman, John, 1952-

- Why Reconciliation? A Response to Critics [Access article in HTML] [Access article in PDF] Subjects:

- Sampson, Steven L. From reconciliation to coexistence.

- Wilson, Richard, 1964- Justice and retribution in postconflict settings.

- Falk, Richard A. Doubting the unconditional need for retribution.

- Nader, Laura. Departures from violence: love is not enough.

- Reconciliation.

Select a Volume

$-\cdots--\cdots--\cdot-\cdots-\cdot$ 

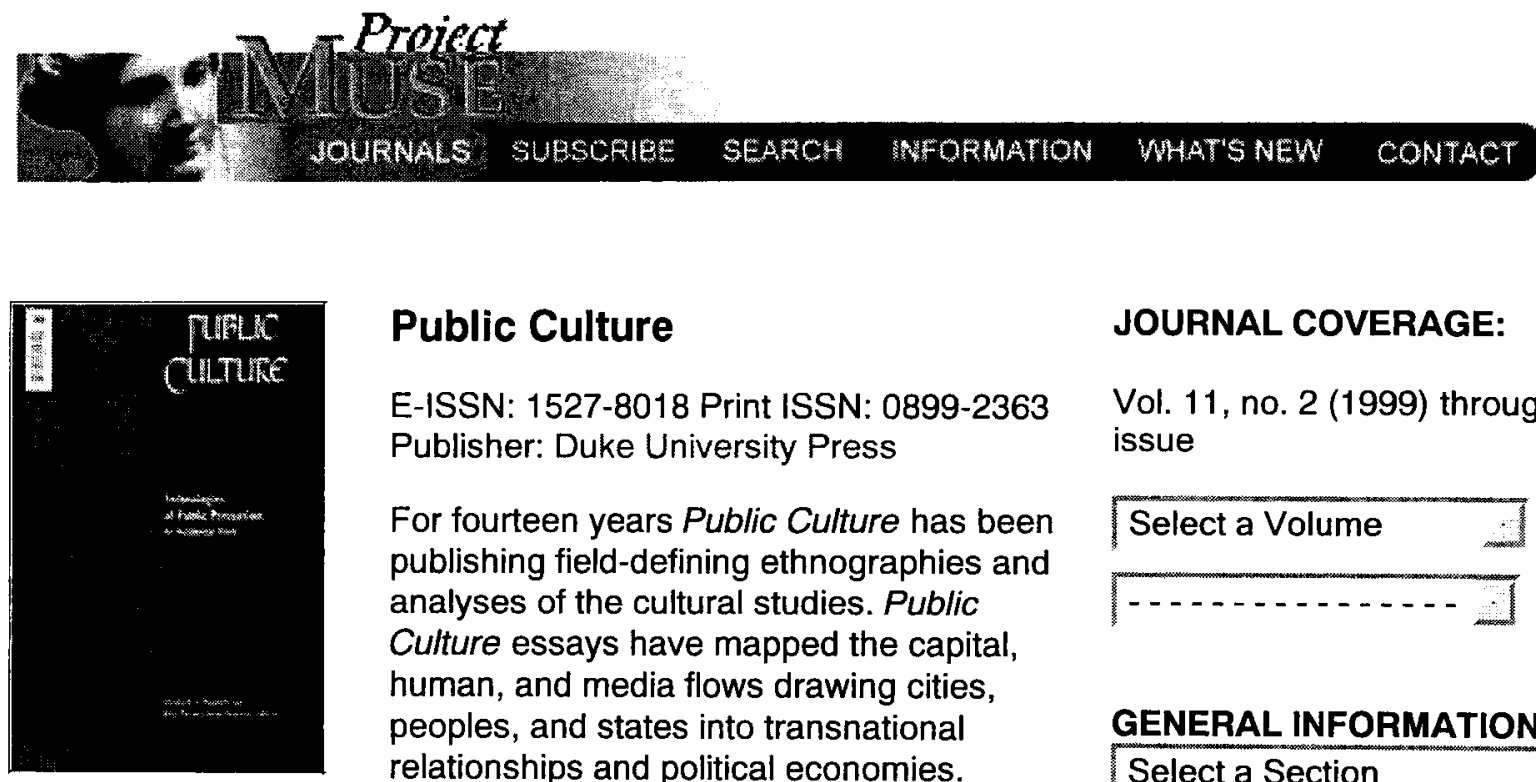

\section{Public Culture}

E-ISSN: 1527-8018 Print ISSN: 0899-2363

Publisher: Duke University Press

For fourteen years Public Culture has been publishing field-defining ethnographies and analyses of the cultural studies. Public Culture essays have mapped the capital, human, and media flows drawing cities, peoples, and states into transnational relationships and political economies. Anthropologists, historians, sociologists, artists, and scholars of politics, literatures, architecture, and the arts have made groundbreaking contribution in the pages of Public Culture.

\section{JOURNAL COVERAGE:}

Vol. 11, no. 2 (1999) through current issue

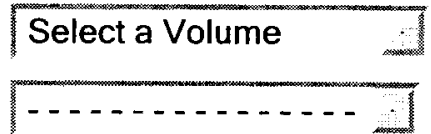

GENERAL INFORMATION

Select a Section 
Public Culture 15.1 (2003) ix

Muse Search Journals This Journal Contents

Access provided by Univ of Technology @ Sydney

[Access article in PDF]

\section{Editor's Note}

This issue of Public Culture was produced in conjunction with the Late Liberalism Project of the Center for Gender Studies at the University of Chicago. In 2000-2001, the Late Liberalism Project sponsored a series of lectures, workshops, and colloquiums to critically interrogate the imaginaries and practices of a variety of global social movements and contestations, some self-consciously liberal, some self-consciously not, others working to free themselves from the grip of this seemingly inevitable choice-to be or not to be liberal. The conceptual linkage of violence and redemption offered a particularly rich place to begin rethinking the genealogies of liberalism outside its own terms. In October 2001, the Late Liberalism Project sponsored a conference on Violence and Redemption to start a discussion on the subject of this special issue. Some of the essays collected in this issue were first presented at the conference. These discussions were generously supported by the University of Chicago's Provost's Office, the Lesbian and Gay Studies Project, and the Department of Anthropology's Lichtstern Fund, and by the Center for Transcultural Studies. Members of the Late Liberalism Project's collective are Lauren Berlant, Elaine Hadley, Charles Hirschkind, Saba Mahmood, Patchen Markell, Elizabeth A. Povinelli, Michel-Rolph Trouillot, and Candace Vogler. It is fortuitous that the responses to John Borneman's essay and his reply are also contained in this issue since they speak so directly to its theme.

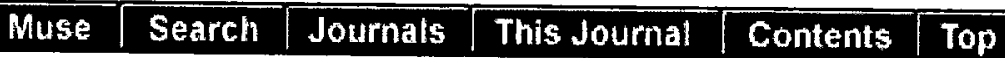

http://muse.jhu.edu/journals/public_culture/v015/15.1povinelli.html 